\title{
The China Challenge: Shaping the Choices of a
}

\section{Rising Superpower}

\section{Thomas J. Christensen \\ New York: W.W. Norton \& Company, 2015}

Anmeldt av Bjørn Klouman Bekken ${ }^{\star}$, MPA, Harvard, underdirektør $i$ utenriksministerens sekretariat, Utenriksdepartementet

Det finnes en yrkesvei i skjæringspunktet mellom akademia og politikk i ÙSA, som i mindre grad finnes i Europa. I både det amerikanske Utenriksdepartementet og Forsvarsdepartementet er det vanlig at akademikere får tunge politiske posisjoner. Dette skyldes delvis at det er mange flere politiske utnevnelser i USA, men nok også delvis fordi deler av amerikansk akademia er mer policy-rettet enn hva som er vanlig i Europa. ${ }^{1}$ Nåværende forsvarsminister Ash Carter var tidligere professor på Harvard. Professor Joe Nye har hatt politiske stillinger i både Pentagon og State Department. Andre kjente eksempler er Anne-Marie Slaughter, Richard N. Haass, og Henry Kissinger.

Et mindre kjent eksempel er Thomas J. Christensen. Han er nå professor ved Princeton, og var i 2006-2008 «Deputy Assistant Secretary of State» i amerikansk UD. Resultatet av at det er noe mer rotasjon mellom akademia og politikk i USA giør at avstanden blir i hvert fall noe mindre mellom de to leirene. Akademikerne som til slutt returnerer til akademia har en større forståelse av den mer praktiske utførelsen av utenrikspolitikken, og det kan igjen resultere i bøker som Christensens The China Challenge. Noe av det mest interessante med denne boka er de gangene den kombinerer akademisk analyse med selvopplevde eksempler fra utenrikspolitikken. For mens Christensen som akademiker har argumentert for at ingen annen aktør har giort mer for å fasilitere Kinas framvekst siden 1978 enn nettopp USA, blir han bare møtt med hoderystning og dyp skepsis når han forsøker å fortelle dette til sine kollegaer i kinesisk UD.

Det er verdt å dvele litt ved bokas undertittel, Shaping the Choices of a Rising Superpower, ettersom den sier mye om både bokas grunntone og formål. For boka

\footnotetext{
^Korrespondanse: Bjørn Klouman Bekken, Utenriksdepartementet. Email: bjornbk@gmail.com ${ }^{1}$ Mens man i Norge bare får noen få politiske utnevnelser med en ny regjering, som en minister, 1-3 statssekretærer, og en politisk rådgiver i hvert departement, er utskiftningen fra en administrasjon til en annen mye større i USA, hvor store deler av toppledelsen byttes ut. Og mens de fleste av disse stillingene fylles av politikere og byråkrater, fylles også noen av disse stillingene av personer med en delvis annen bakgrunn, som fra akademia.
} 
handler om hvordan USA og dets allierte kan påvirke Kina slik at de i større grad tar mer internasjonalt ansvar, og blir en mer konstruktiv partner for USA. Christensen skriver at USAs hovedstrategi bør være å vise at Kinas «nasjonale storhet» kan best oppnås gjennom samarbeid, ikke konfrontasjon. USA må forsøke å påvirke den framvoksende stormakten slik at de tar framtidige valg som er i begges interesse.

Boka skriver at fremskrittene internt $\mathrm{i}$ Kina de siste tiårene har vært så voldsomme - med hundrevis av millioner som er løftet ut av fattigdom, med vekst i BNP per person fra USD 200 til over USD 5000 - at det er vanskelig å bruke betegnelsen «like dramatisk» om noe som helst annet. Christensen argumenterer imidlertid for at man nesten kan si at utviklingen i Kinas forhold til omverdenen har vært like dramatisk. Kina har gått fra å ha minimalt med handel med omverdenen til å bli en den største handelspartneren til over 100 land. På høyden av den kulturelle revolusjon på slutten av 60-tallet hadde verdens mest folkerike land bare én ambassadør i utlandet (!), mens i dag har de sendt en ambassadør til selv de minste afrikanske hovedstedene, som Niamey, Conakry, og Moroni. Men Christensen understreker også klart hvorfor Kina i overskuelig framtid vil forbli langt bak USA: det kinesiske militære er mye mindre avansert, de har store strukturelle økonomiske utfordringer, de sliter med korrupsjon og mangel på innovasjon, de har mye mindre diplomatisk innflytelse, og $\mathrm{i}$ motsetning til USA har de knapt en eneste alliert.

Like fullt kaller Christensen Kinas framvekst for kanskje den største utfordringen for amerikansk diplomati i det 21. århundre. Forholdet mellom stormaktene på hver sin side av Stillehavet er ikke et nullsumspill, men utfordringer $\mathrm{i}$ alt fra handelspolitikk til grenser i Sørkinahavet gjør det til en krevende balansegang. "The trick for US leaders is how to maintain a strong military, economic, and diplomatic presence in East Asia, without triggering a defensive and destabilizing reaction in Beijing» (293). USA må jobbe for at Kina ikke destabiliserer Øst-Asia, samtidig som de må oppmuntre Kina til å ta mer internasjonalt ansvar, i alt fra humanitær nødhjelp til kampen mot global oppvarming.

Boken skriver samtidig at man må ha noe tålmodighet med Kina, ikke minst fordi aldri før har «a country as relatively poor as China on a per capita basis held such an important and powerful position in the international system» (xx). Men nettopp fordi det internasjonale systemet har muliggjort Kinas framvekst de siste tiårene, er det nå på tide at Kina tar mer internasjonalt lederskap i møte med felles globale utfordringer, argumenterer Princeton-professoren.

Christensen bestreber åpenbart å være balansert i sin framstilling. Tidvis blir det nesten for mye «på den ene siden og på den andre siden». Men det er også en av bokas styrker. I motsetning til mye annet som er skrevet om Kinas framtid er dette verken en alarmerende eller overoptimistisk bok. The China Challenge har en mer nyansert og pragmatisk tone. For først og fremt er dette en imponerende bok, som blander historisk overblikk med klare analyser, detaljert empiri med noen interessante anekdoter.

Boka kan også leses som en introduksjon til hvordan det amerikanske utenrikspolitiske etablissementet ser på utfordringene og mulighetene knyttet til Kinas framvekst. 